\title{
The Role of the Villain as A Determinant of the Existence of the Main Character
}

\author{
Anindya Putri Pradiptha, M. Hum. \\ Universitas Budi Luhur, Jakarta, 12260 \\ Telp: (021) 5853753/0852 49469026 \\ Email: anindya.putri@budiluhur.ac.id
}

Article History: Submitted 31 May 2018; Accepted 1 June 2018; Published date 28 June 2018

\begin{abstract}
Comic is one of the popular literary works that combining pictures and languages. It can be a work if it consist of story that using language as the medium. The aims of this study is to explain the formula of the comic by using theories of comic, escapism, and the narration's structure of an adventure comics, The Life and Times Of Scrooge McDuck created by Don Rosa. To get relevant data, this study is employ one method, namely; library study. In this paper, the writer used theories of comic by Scott McCloud, escapism by Cawelty, and the narration's structure of Vladimir Propp. The result indicates that in this comic, there is the reality of the idea that the existence of the main character is manifested by the presence of the villains. Comic is a complete books that can teaching the reader which is not only understand the stories, but also the world view inside, it is the good ideology of the existence from the bad side.
\end{abstract}

Keywords: comic, escapism, narration, existence, and the villains.

Abstrak. Komik adalah salah satu karya sastra populer yang menggabungkan gambar dan bahasa. Hal ini dapat bekerja jika itu terdiri dari cerita yang menggunakan bahasa sebagai media. Tujuan dari penelitian ini adalah untuk menjelaskan formula komik dengan menggunakan teori komik, melepaskan diri, dan narasi struktur komik petualangan, hidup dan Gober Bebek dibuat oleh Don Rosa. Untuk mendapatkan data yang relevan, studi ini menggunakan satu teknik, yaitu; $\backslash$ studi perpustakaan. Dalam tulisan ini, penulis menggunakan teori Komik oleh Scott McCloud, eskapisme oleh Cawelty, dan struktur narasi Vladimir Propp. Hasilnya menunjukkan bahwa di komik ini, ada realitas gagasan bahwa keberadaan karakter utama diwujudkan oleh kehadiran penjahat. Komik sebuah bacaan yang berisi, mendidik, dan berbobot, karena melalui komik pembaca tidak hanya memahami ceritanya saja, tetapi realitas ide di baliknya, yakni ideologi baik dari keberadaan si pelaku kejahatan.

Kata kunci: komik, eskapisme, narasi, keberadaan, dan para penjahat. 


\section{INTRODUCTION}

Comic $^{1}$ is one type of popular literature is able to combine visual form, either in the form of the pictures or languages (words). That combination gives rise to a certain aesthetic impression achieved by recovery. It is not only that the story is also refining the results from a comic. As with other works of literature, comics can also provide pleasure for the readers. There are three experiences (triple effects) that the reader felt when and after reading comics, namely the experience of escape, ecstasy, and catharsis that appear simultaneously. Of course, there is only the third effect that spurred the writer to make the paper. What things that make the comics can be ' hypnotized ' readers so that can cause multiple effects like that. Whether it is comes from a fun, sad, painful, or scary.

Comics have properties and characteristics of literature because comics have a blend between images of beauty, color, and text (language). Comics use the image as one of the Visual medium and language as a complement, because language is a secondary modeling system (model system) that apply universally (Ajidarma, 2011). The existence of the characterization of the ages as the fact that why comic is represented in other comics as a literary work. Therefore, the comic is one of the popular literary works that can combine visualization and imagination, narration, or may also be referred to as one of the media of visual communication.

The media called the comic is based on a simple idea, namely the idea of placing a picture after picture of another, which was also to show the passage of time. The power of this idea is not limited, but constantly blinded by its limited in popular culture. To understand comics, the form needs to be separated from the content, so that it looks obvious how other ideas at the time it has been used with wonderful results, and how the limited tools and ideas that prevail today.

The comic is a variety of language, its treasury is all the capabilities of visual symbols, including the ability to make cartoons or pictures realist, separately or in combination. The heart of a comic is located on the panels, an important collaboration between the imaginations of readers who were able to revive the comic. A process that is could be classified, and can even set although it will still render its methods in a mysterious psychological abuse. Comics that are rely on visual sequence, also capable of replacing time with space, although none have looked confused and time flows through the comic in its own way.

In this paper, the writer only takes one kind of comic, it is an adventure comics, namely with the title The Life and Times of Scrooge McDuck (TLTSMD) by Don Rosa that consists of 12 series. The use of such comics as an object of the research, because the content of stories in an adventure's comic is the reality of the ideas expressed. As the role of the villain against the main character in the Scrooge McDuck comic and as a character who 'perfected' the existence of the main character. In real life, people are very frustrated by the villains who disrupt them, but in the comic story of a fight between the villains and the main character is fun to be 'listened' to. The exclamation point became ' sedative ' for readers.

\footnotetext{
1 McCloud (2001:20-21) in his book Understanding Comics, comics is a noun in the plural form, used with singular verbs. In the form of a single panel, drawings, and other symbols that juxtaposed in a certain sequence, aims to provide information and the aesthetic stage or reach the reader.
} 


\section{Comics}

Comic book writers use theory is a theory of Scots McCloud. According to McCloud in his book Understanding Comics,

Comics is a noun in the plural form, used with singular verbs. In the form of a single panel, drawings, and other symbols that juxtaposed in a certain sequence, aims to provide information and or reach stages aesthetically readers (2001: 20-21).

In comics, the use of pictures and symbols aligned in accordance with the conditions. The purpose of the aligned between the image and the coat of arms is to provide specific information or message, due to aesthetic stage brings the comic reader. The aesthetic stage is a composition between figure and symbol of the parallel, or the use of the colors which can embellish stories in comics.

The comic consists of the formulation of panels, balloons, and colors. Based on the above definition, in this research will be spelled out, such as the TLTSMD comic book formulation panel, balloons, and color, related to work ethic described in section later comicology.

The existence of the pictures and symbols that are aligned with the provisions which have the purpose to inform or give specific message with the aesthetic stage brings the comic reader. Only through one's senses of sight, comics are able to enable the whole of the senses through images that are understandable by the readers. Through the character lines that comics were able to bring the world of emotions that are not visible. The lines became symbols in themselves, and then collaborate together younger symbol again, i.e. the words. As the story of Adam and Eve who has been separated for hundreds of years, the lines and words establish rapport that is closer than any other form. As any other medium, comic is not just a simple idea that in the search for a complex application. The comic still disdained as not a conventional wisdom by art. A status which seek embattled though many also in that community who enjoyed it.

Comic position in society is vital, as one of the few forms of personal communication, in a world that is formed of automatically things and marketing department. The comic features a media control and the incredible lightness of being to the composers, something unique, intimate relationships with the public, and a potential is so great, so inspiring, is wasted in a brutal and useless ${ }^{2}$.

\section{Escapism}

As has been outlined previously, reading comics is an effective way to improve the experience of escape, ecstasy, and catharsis. According to Cawelty in his writing, in the popular literature of Escapism involved two Psychological needs (1976, 15-16). The first requirement is to find pleasure and intense pleasure to escape the boredom, experienced by the majority of modern people. The second requirement is at the same time the reader would like to escape from his awareness about the lack of security and ambiguity that hit their lives, such as the threat of terror, the villain, the death, failure in love, and so on. Experience the ecstasy and catharsis obtained after the experience of the escape happened. The presence of contentment and curiosity that are continues after reading comic. Of

\footnotetext{
${ }^{2}$ Summary of Understanding Comics (Jakarta: Gramedia Popular Libraries, 2001) is in Reinventing Comics (New York: DC Comics, 2000).
} 
course as popular literature, comic has a formula that is not only deals with the things above, but also discussing the character in the story, as will be noted in this paper.

\section{The Narrative's Structure of Vladimir Propp}

Propp said that the story was basically having a construction. The construction of these motif are divided into three elements, i.e.; the perpetrator, deeds, and sufferers. A fixed element is the Act, whereas the element being changed is the perpetrators and sufferers. He started with classification and organizing folklore. In inductive, Propp classifying it in four formulas, (1) the functions of the characters as the stabilizator, of fixed elements in a story, it does not depend on how or by whom they met. These elements form the fundamental components of a story. (2) The number of known functions in the fairy story is limited. (3) A series of functions that are always identically. (4) All fairy stories consist of one type of structure.

In comparing the functions of those tales, Propp found that the number of overall functions of not more than thirty-one functions ${ }^{3}$. He called the seven first functions as a unit of preparation. Its complications are marked with the number 10, followed by displacement, struggle, return (the return), and the introduction. In addition to thirty-one such function, Propp adds seven "rounds of action" (Spheres of action), as follows: villain, donors (provider), a helper, a daughter and his father, the Messenger (dispatchers), Hero (search/victim), and the false hero. The author uses the structure of the narrative model of Propp, because comics are analyzed is part of the fiction in which the narration structure in accordance with the model.

Comics are usually defined as pictures, symbols, or texts that are aligned to produce a story, in which the story is aimed to reach the stage of aesthetic or contain information in it. Literary works of this one really needs a mysterious cooperation between the Indonesian and the reader. The synergizes of the readers with the idea that poured by the comic artists.

When reading the comic readers are able to turn the whole content of the story. Reading comics of course different when a person reading another reading, when a person reads a novel only eye senses are active, because it is only through the narrative seem visually; Meanwhile, while reading the comics throughout the five senses active functioning only through the senses of eyes only. Why is this so? Through images that are created in such a way, and cartoonists are able to represent his imagination over the expression of the characters and the atmosphere in the story. The atmosphere of the day, happy, even though gripping the reader can be felt when reading the comic. Just scrapes through pictures, voice, mood, the smells, and feelings can enable the entire senses that. The idea of comics contained straight visually, so that the imagination of the reader to follow what is written the comic visually anyway. Of course it is different when reading a novel, the leap of imagination or interpretation is certainly different from everyone over the atmosphere especially figure imagined by the readers.

Based on the main question, the issue will be discussed in this paper can be formulated as follows:

\footnotetext{
${ }^{3}$ By Bob Ashley (1989) in Reading Popular Narrative; Formula, genre and the structuralist analysis of narrative, Vladimir Propp, Morphology of the folk tale p. 94-96.
} 
1. How do the characters (the identity of) animals as the villains and evil villains that are present in every story of adventure as a factor the cradles of the exclamation point of the content of the story?

2. Why is the role of the villains known as determining the existence of a main character?

3. What is the function of the villains in the adventure's comic?

\section{METHOD}

Comic is a literary work that is imaginative, he was confined to a narrow space there are namely in the form of pictures. From the narrow space is a problem that can be described using a narrative's structure. How the comic work is an imaginative literary expressed and can be a media of ideological struggle that can be formulated in descriptive through the method of narrative's structure.

\section{RESULTS AND DISCUSSION}

The analysis of contents is divided into three section later answered the third formulation of the problem above.

Table 1 The Profile of The Villains

\begin{tabular}{|c|c|c|c|c|}
\hline Chapter & $\begin{array}{l}\text { Series, the } \\
\text { setting } \\
\text { and the } \\
\text { time }\end{array}$ & $\begin{array}{c}\text { The identity of } \\
\text { the villain }\end{array}$ & $\begin{array}{l}\text { Crimes } \\
\text { committed }\end{array}$ & Picture \\
\hline \multirow{5}{*}{0} & \multirow{2}{*}{$\begin{array}{l}\text { Of Ducks } \\
\text { and Dimes } \\
\text { and } \\
\text { Destinies }\end{array}$} & $\begin{array}{l}\text { Name: Magica De } \\
\text { Spell }\end{array}$ & \multirow{5}{*}{$\begin{array}{l}\text { always trying to } \\
\text { take the first coin } \\
\text { of Scrooge } \\
\text { McDuck } \\
\text { talismans. }\end{array}$} & \\
\hline & & Profession: Witch & & \\
\hline & \multirow{3}{*}{$\begin{array}{l}\text { Skotland, } \\
\text { Year 1867- } \\
1880 .\end{array}$} & $\begin{array}{l}\text { Physical } \\
\text { characteristics: the } \\
\text { female Duck, } \\
\text { dressed in black, } \\
\text { shoulder length } \\
\text { black hair, make up } \\
\text { face gothic. }\end{array}$ & & \\
\hline & & $\begin{array}{l}\text { Character: } \\
\text { perseverance, a } \\
\text { little good natured. }\end{array}$ & & \\
\hline & & $\begin{array}{l}\text { Weapon: magic } \\
\text { wand. }\end{array}$ & & \\
\hline 1 & $\begin{array}{l}\text { The Last Of } \\
\text { The Clan } \\
\text { McDuck }\end{array}$ & $\begin{array}{l}\text { Name:The } \\
\text { Whiskerville }\end{array}$ & $\begin{array}{l}\text { McDuck family } \\
\text { neighbor that } \\
\text { always claimed }\end{array}$ & \\
\hline
\end{tabular}




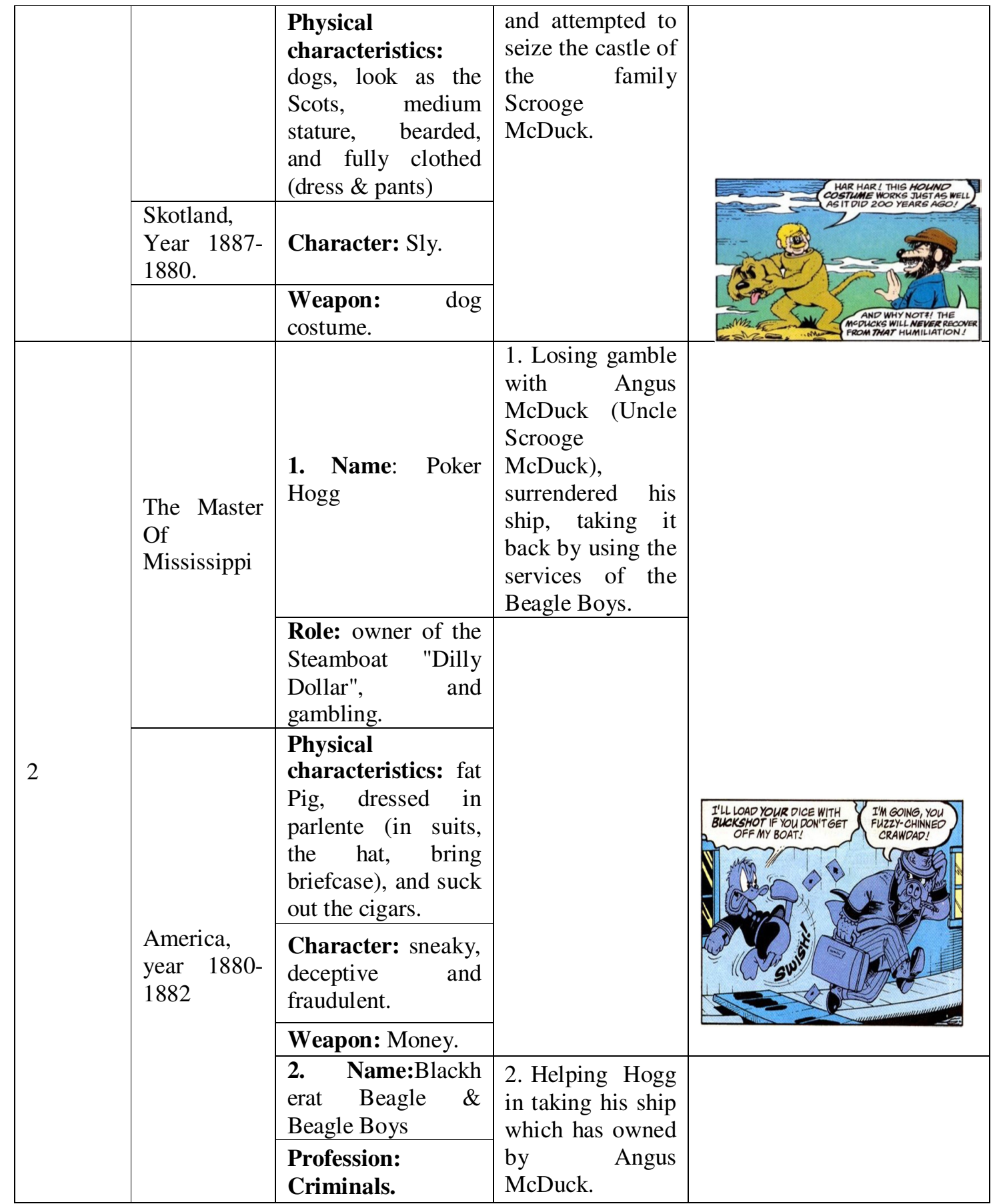




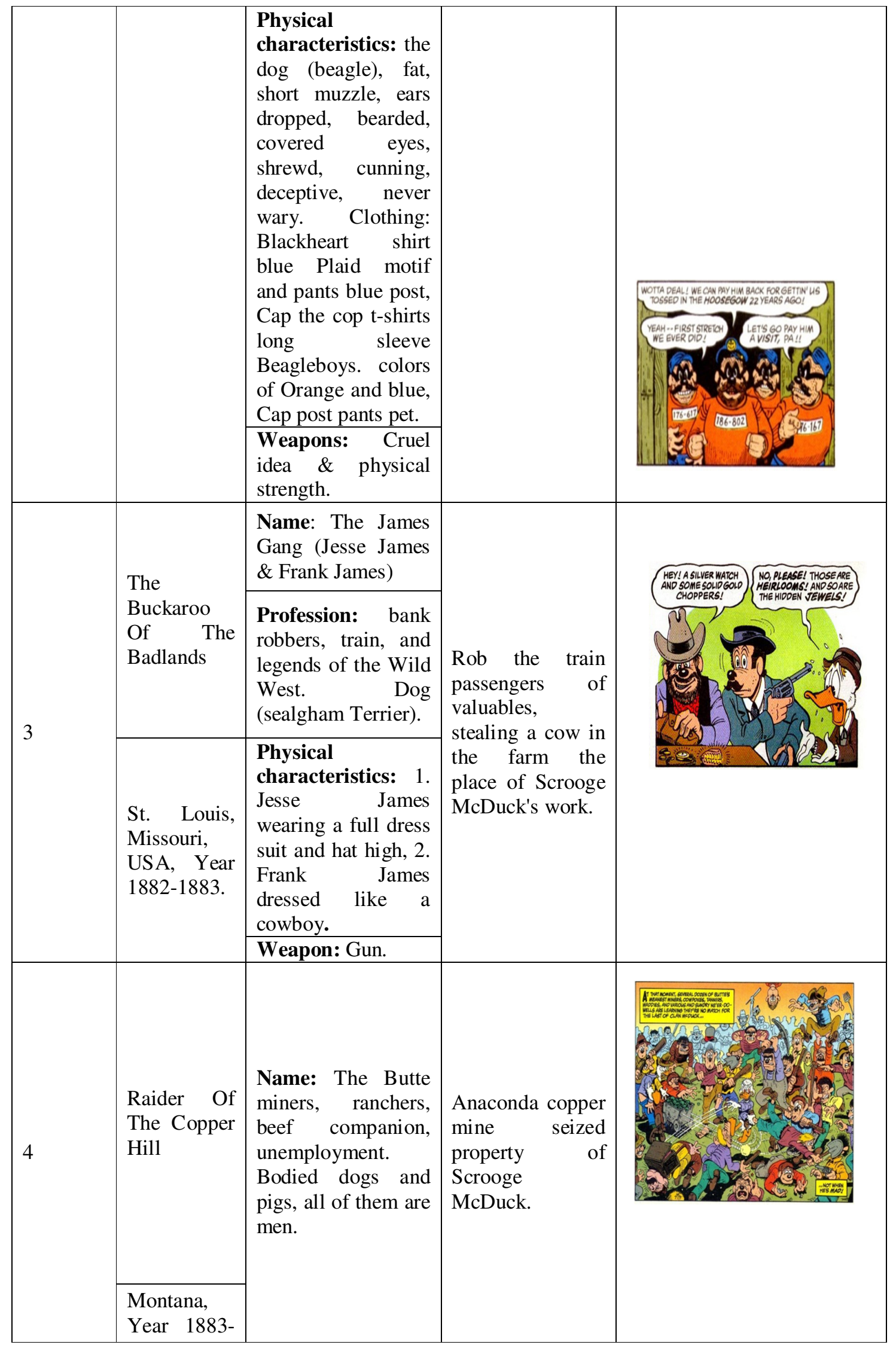




\begin{tabular}{|c|c|c|c|c|}
\hline & 1885. & & & \\
\hline \multirow[t]{2}{*}{5} & $\begin{array}{l}\text { The New } \\
\text { Laird of } \\
\text { Castle } \\
\text { McDuck }\end{array}$ & \multirow[t]{2}{*}{$\begin{array}{l}\text { Name: } \\
\text { Whiskerville } \\
\text { family (the same } \\
\text { as on the identity } \\
\text { column 2) }\end{array}$} & \multirow[t]{2}{*}{$\begin{array}{l}\text { The same as the } \\
\text { chart title series } \\
\text { The Last Of } \\
\text { The Clan } \\
\text { McDuck. }\end{array}$} & 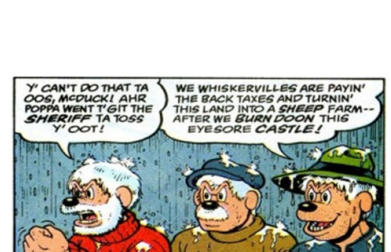 \\
\hline & $\begin{array}{l}\text { Skotland, } \\
\text { Year } 1885 .\end{array}$ & & & \\
\hline \multirow{4}{*}{6} & & $\begin{array}{l}\text { Name : Kruger } \\
\text { Duck }\end{array}$ & \multirow{4}{*}{$\begin{array}{l}\text { Like stealing } \\
\text { the belongings } \\
\text { of the other } \\
\text { miners, boasted } \\
\text { so that other } \\
\text { people believe } \\
\text { him, and steal } \\
\text { Scrooge } \\
\text { McDuck stuff. }\end{array}$} & \\
\hline & $\begin{array}{l}\text { The Terror } \\
\text { Of } \\
\text { Transvaal }\end{array}$ & $\begin{array}{l}\text { Physical } \\
\text { characteristics: } \\
\text { the Ducks look } \\
\text { seedy, dressed in } \\
\text { a peasant hats. }\end{array}$ & & \\
\hline & \multirow{2}{*}{$\begin{array}{l}\text { Africa, } \\
\text { Year 1886- } \\
1889 .\end{array}$} & $\begin{array}{l}\text { Character: } \\
\text { tricksters, thieves, } \\
\text { and a liar. }\end{array}$ & & \\
\hline & & $\begin{array}{l}\text { Weapon: the } \\
\text { deception } \quad \text { of } \\
\text { innocent faces and } \\
\text { gibberish. }\end{array}$ & & \\
\hline \multirow{4}{*}{7} & \multirow{2}{*}{$\begin{array}{l}\text { Dreamtime } \\
\text { Duck Of } \\
\text { The Never } \\
\text { Never }\end{array}$} & $\begin{array}{l}\text { Name: Dalton } \\
\text { (Junior) Brothers. }\end{array}$ & \multirow{4}{*}{$\begin{array}{l}\text { Rob traveler } \\
\text { and aborigines } \\
\text { Baiduri gems } \\
\text { seized. }\end{array}$} & \multirow{4}{*}{ 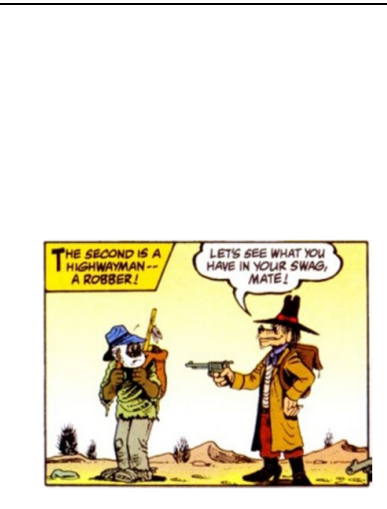 } \\
\hline & & $\begin{array}{l}\text { Profession: } \\
\text { Robbers in the } \\
\text { desert. }\end{array}$ & & \\
\hline & \multirow[t]{2}{*}{$\begin{array}{l}\text { Australia, } \\
\text { Year 1893- } \\
1896 .\end{array}$} & $\begin{array}{c}\text { Physical } \\
\text { characteristics: } \\
\text { the dog, thin, } \\
\text { bearded, fully } \\
\text { clothed, and hat. }\end{array}$ & & \\
\hline & & Weapon: Gun. & & \\
\hline \multirow[b]{3}{*}{8} & \multirow{2}{*}{$\begin{array}{l}\text { King Of } \\
\text { Klondike }\end{array}$} & $\begin{array}{l}\text { Name: } 1 . \text { Wyat } \\
\text { Earp }\end{array}$ & \multirow[b]{3}{*}{$\begin{array}{l}\text { 1. make trouble } \\
\text { when about to } \\
\text { Scrooge } \\
\text { McDuck treats } \\
\text { at the bar. }\end{array}$} & \multirow[b]{3}{*}{ (D) } \\
\hline & & $\begin{array}{l}\text { Role: fraudsters } \\
\text { \& rioters. }\end{array}$ & & \\
\hline & $\begin{array}{l}\text { Klondike, } \\
\text { Yukon, } \\
\text { Year 1896- } \\
1897 .\end{array}$ & $\begin{array}{c}\text { Physical } \\
\text { characteristics: } \\
\text { dogs, mustache, } \\
\text { hair, hat, tify up, } \\
\text { look complete and } \\
\text { presentable (suit, } \\
\text { hat, shoes), thin, }\end{array}$ & & \\
\hline
\end{tabular}




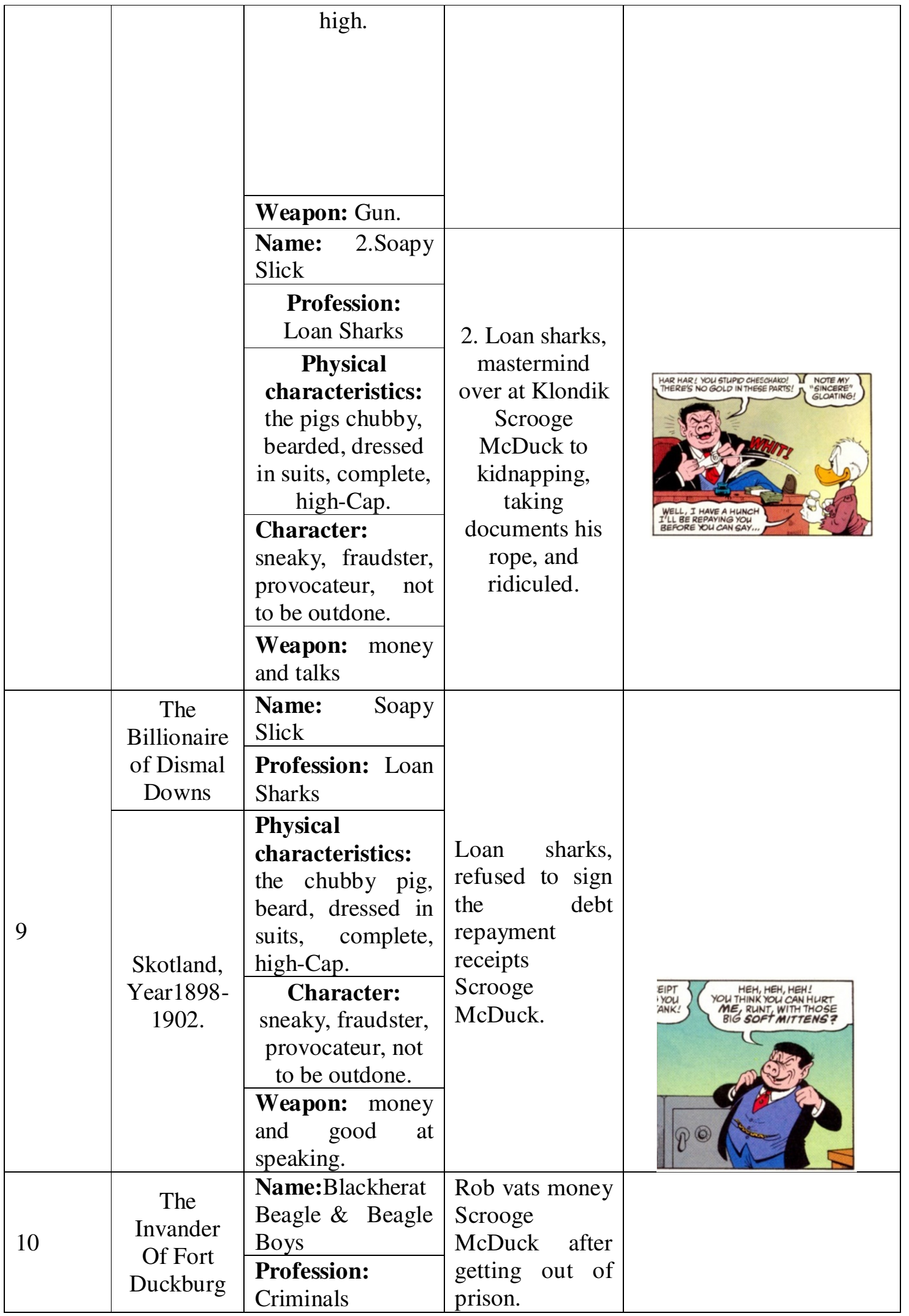




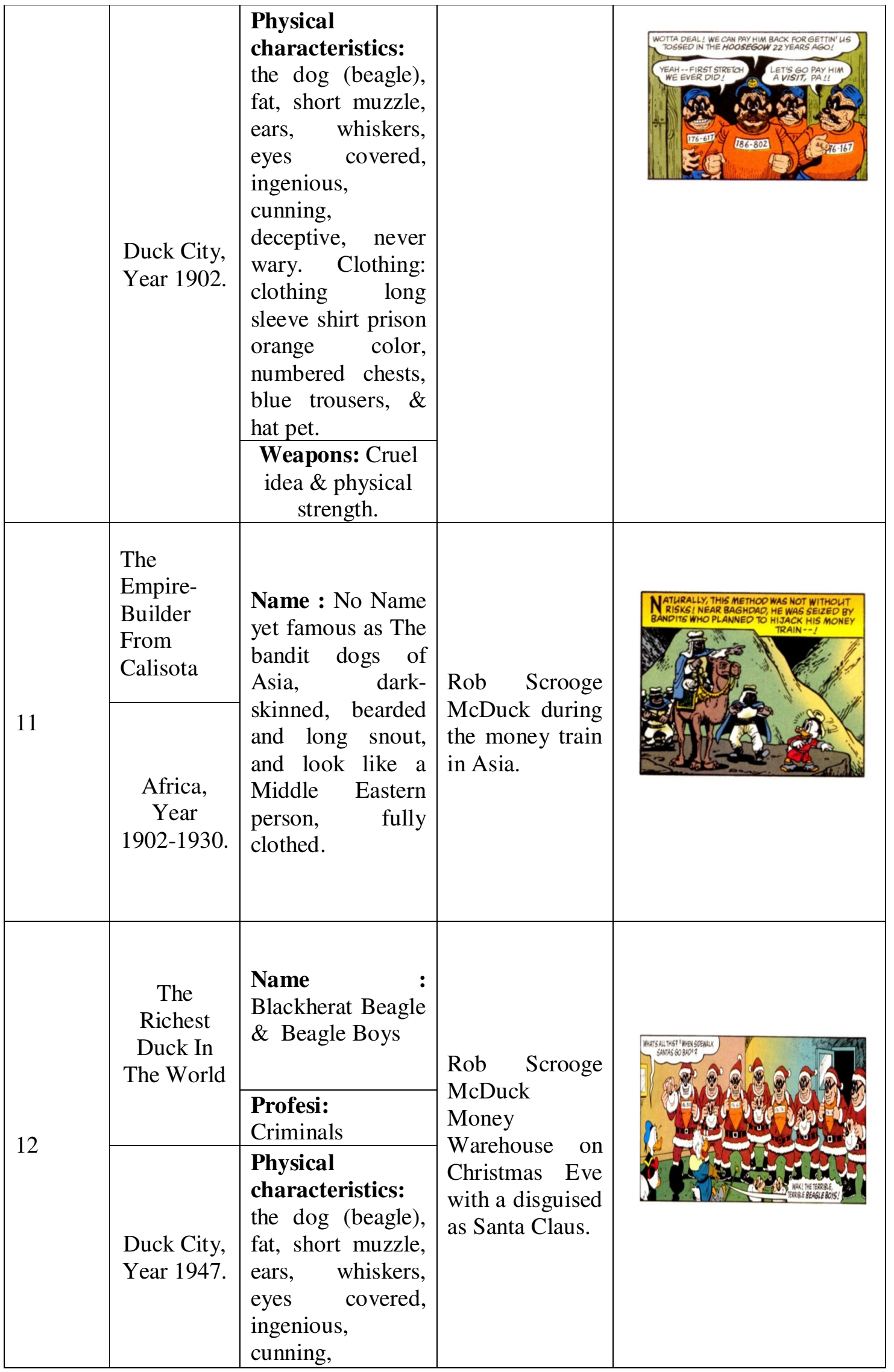




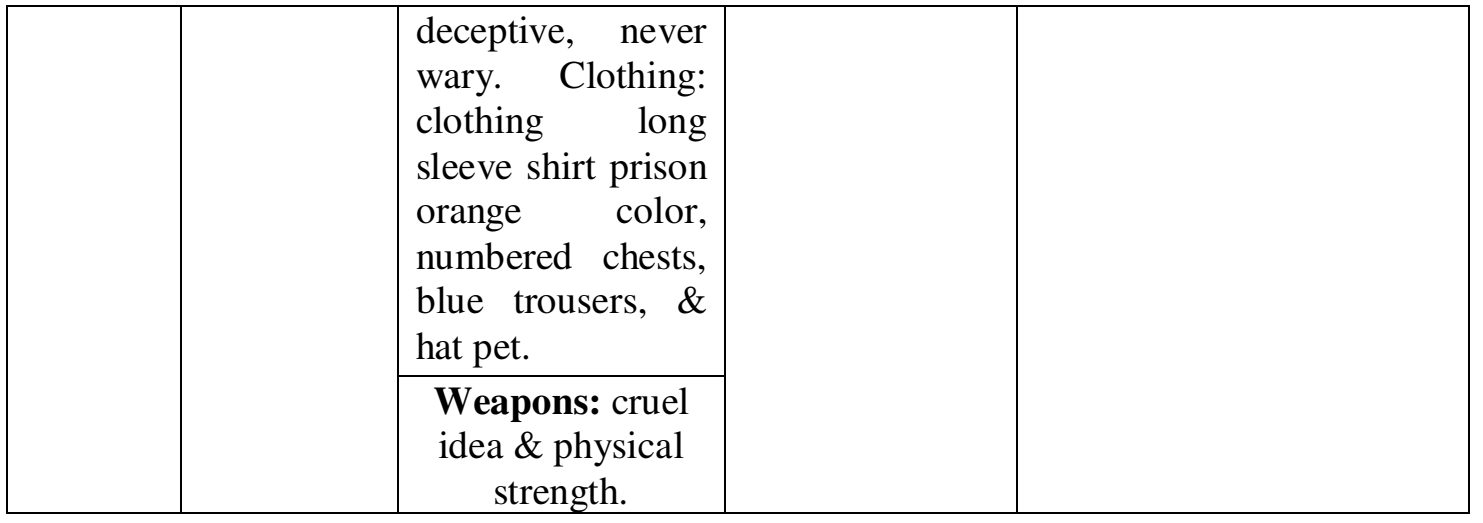

Based on the identification of criminals above, there are three types of animals that represent it, i.e; ducks, dogs, and pigs. Each villain has the physical characteristics, goals, and different weapons. The first analysis was the duck. Magica De Spell is a duck's magician, in the story she just wants to get the first Scrooge McDuck's chips by using her magical abilities. These pieces are rated as ' seasoning ' key for amulets that will make him the greatest ruler of the Mountain Witch Vessuvius. According to the author's analysis, the duck is the personification of a human being. In real life, however, man uses magic to get what they wanted. This is can be considered a form of satire against man, which still believed in things mystical and use it if the power of logic cannot cope with her will. The next duck figure was Kruger Duck. The writer interpretation, he was included in ' type ' will be an inspiring man crap, hypocritical, and flatterers, who use these talks to ' steal '.

The next character is a character analysis of the dog's diverse kind depends on the setting of the story. The dog, the authors interpret as ' type ' man more. In the real life, dogs are ' friends ' of the faithful with his master (a man), and is also often used in human activities such as hunting and guarding livestock, but in the comic its played back, the character as a man as a villain because of the entire cast of ' trivial ' dogs wearing clothes and armed with a pistol, complete while wearing only duck figure tops only. There is a tendency that leads to social satire, where the ' perfect man ' was not necessarily as perfect as his appearance, because what looks good is not necessarily good (ad hominem, there is good and bad; right and wrong). While the pig figures, the writer means as a cunning man, likes to take the rights of others, and greedy as its fat.

Please note carefully regarding weapons used by the ducks, dogs, and pigs. On the character of the duck, both of them are using the ' ability ' of his own. Magica De Spell uses magical power which she learned by herself, while using her expertise in Duck Kruger spoke. Then the figures of dogs, all of which use physical force and weapons, it indicates the power level more than human (could have been the apparatus), namely, the use of more sophisticated weapons and powerful. Next on the pig figures, both use money as a weapon, because pigs are identical to the corruptor (human) who likes to bribe and dredge show gains.

If readers of its comics are children, the use of animal characters could have been fun (to lull the reader kids), because you can see the animals talk, wearing cloth, and behave like humans. While, for the writer, the role of animal characters such as animalization of the nature and habits of the man looks like. This comic as a social satire, who wanted to ' 
flicking ' the readers which is human. As it was said Cawelty, in literature of popular culture there are formulas that are represented.

\section{Basic Narrative Scheme (Vladimir Propp)}

The story in the comic starting from the narrative delivered by the narrator as well as the objects contained in the prologue as a guide the whole story. The following schemes are essentially narrative:

1. Initial Situation, the narrator tells the prologue which refers to the overall content of the story.

2. The shortage/need Scrooge McDuck arrived in a city to get started/get a job.

3. Mediation, Scrooge McDuck get work from other people of the existence of the connecting events.

4. The fight, Scrooge McDuck was hated, got interference from the villains, local residents, concerned with the bullies, or local governments was compounded his efforts.

5. Scrooge McDuck, Struggle against the harrasment and retain the business which he incubated.

6. Scrooge McDuck got the victory, a result of gave and won against the villains and succeed in the business which he incubated.

7. Recognation, Scrooge McDuck became respected and famous duck as duck tough.

Based on the table before, almost every adventure Scrooge McDuck intersect with the criminals. The purpose of these same the villains, i.e. seizing something valuable from Scrooge McDuck. The early presence of any villains, some are arriving from the future to take pieces of luck as a profession (Magica De Spell), robbing other people first, helping launch other party coveting Scrooge McDuck, and so on. The readers will be lulled by the recovery about crimes that have been committed by the villains. It is true of crimes happening in the real world, in a world of fantasy, crime remains contrived very exciting maybe even though there are elements of violence but delivered with typical ' readings for kids ' is full of action, funny, and entertaining.

The suspense from the exclamation which is in the comics are not only from the stories of the adventures of Scrooge McDuck full action when the fight baddies both physically and intellectual, but at the animal figures. The figures then assimilated in the human characters in the form of animals (animalization). Fantasy offered by comic make anything can occur, such as animals dressed and spoke like a man, this should be controlled by the readers. The exciting scene were happened when Scrooge McDuck against the villains can cause a feeling of excess for the reader so that escape, relaxation, ecstasy, and chatharsis also can occur. Reader satisfied because of the exclamation of the story lies in the fight scenes (of violence), the cartoonist realist visual form (the colors that can stimulate the brain and eyes, reinforced with a facial and behaviour of the characters), and a sense of curious arising after reading it. Therefore, the reader always felt curious will be the next series.

\section{The Role of the Villains Known as Determining the Existence of A Main Character}

Seen from the previous discussion, the existences of each villain were presented in every story of the adventures of Scrooge McDuck. The appearance, need to Rob, and origin of each different villain. In the comics, the character Scrooge McDuck who ' deemed ' hero, the authors deem its success as the structure of the system governing where the powerful 
always win. The existence of the internal negation between the villains and Scrooge McDuck. The analogues such as the existence of the chair because there are tables if there is no bid vacuum. Its also happenned with Scrooge McDuck, who ' need ' the villains, without them the existence of Scrooge McDuck would not be as a brave adventurer and great. The writer realizes that human beings need challenges in any form, human life will taste bland, and mentally not developed because there is no challenge that means. When the role of the villain defeated Scrooge McDuck here are the explanations through the table hypothesis.

Table 2 The Hypothesis

\begin{tabular}{|c|c|}
\hline Events in Comics & The Hypothesis \\
\hline $\begin{array}{l}\text { Magica De Spell restores the first Scrooge } \\
\text { McDuck pieces. }\end{array}$ & $\begin{array}{l}\text { If the chip is not returned, Magica De Spell } \\
\text { became a well-known witch, then the story } \\
\text { of the adventures of Scrooge McDuck } \\
\text { became filthy rich duck in the world did not } \\
\text { last because there are no pieces that inspired } \\
\text { him to work more actively and to wander. }\end{array}$ \\
\hline $\begin{array}{l}\text { Whiskerville family does not successfully } \\
\text { taken controlled the Castle of the } \\
\text { Mcduck's Clan because Scrooge McDuck } \\
\text { guided by the ghost of Sir Quak to } \\
\text { maintain his family's Castle. }\end{array}$ & $\begin{array}{l}\text { If successfully mastered the Whiskerville } \\
\text { Family Castle of the clan McDuck, because } \\
\text { the ghost of Sir Quak does not come, then } \\
\text { the Scrooge McDuck did not dare to confront } \\
\text { them. The heritage of his family was } \\
\text { captured and his poverty never ends. }\end{array}$ \\
\hline $\begin{array}{l}\text { The Beagle Boys help Poker Hogg seizing } \\
\text { ships steam vats, robbing money and } \\
\text { Shed his money. }\end{array}$ & $\begin{array}{l}\text { Scrooge McDuck became weak minded } \\
\text { individuals who ducks and not become } \\
\text { heroes for children }\end{array}$ \\
\hline Soapy Slick the moneylenders. & $\begin{array}{l}\text { If there is no Soapy Slick, so Scrooge } \\
\text { McDuck could not develop his business } \\
\text { because it does not have a capital. }\end{array}$ \\
\hline $\begin{array}{l}\text { The James Gang, the Dalton brothers, and } \\
\text { robbed the McViper. }\end{array}$ & $\begin{array}{l}\text { If there is not a fight between them, then } \\
\text { there is no adventure exclamation and mental } \\
\text { steel Scrooge is not formed. Scrooge } \\
\text { McDuck became duck cowardly and weak. }\end{array}$ \\
\hline
\end{tabular}

\section{Function of the Villains in the Comic Adventures}

In accordance with both the above analysis, there were raised questions in the minds of the writer regarding the role of the villain in an adventure's comic. Is it only serves as an antagonist, the role of the maid who managed to make the main character's existence, entertainer interlude, or examples of that in this world there is always evil and good as ordained in any Scriptures of mankind? Any impressions and messages that are captured by a reader about the content of the story in the comic are dependent from storage.

For the writer, the message conveyed by the comic narrative in the form of ' jokes ' could be embedded in the mind of the reader especially children, if the mind is merely his 
adventures. Through the character of Scrooge McDuck who actually do not want to lose (though never give up), has been cradled the readers especially for children. In this case, it takes the role of a parent to guide his children in reading comics. So, the fact that comic is intended for the childrens or adult depending on the angle of view of the readers. If kids like the pictorial reading, while adults tend to reading many writings. In the comic that the writer's analyzed, the percentage between the pictures and the narrative (writing) almost just as much.

\section{CONCLUSION}

Based on analysis of problem formulation-the above analysis can answer that comics are generally known as entertainment is not always turns out light reading. The presence of the reality of the ideas behind them, especially comic adventure that loaded will be a battle between the criminals and the main character. The existence of the main character is manifested by the presence of criminals. Animal figures which is the animalization properties and ' types ' diverse human became an attraction on its own in The Life and Time of Scrooge McDuck. The existence of criminals as an antagonist, a barrier to the success of ruthless villains, and it is a ' Hero ' for the main character, though it may just be denied by readers who do not agree.

Comic as one of the media that produces culture has provided the moral messages through the crimes in the content of the story. Violence arising composed is exciting, fun, and regular daily readers, decorate either realized or not. Escapism, ecstasy, and catharsis that reached all at once by its readers can be obtained if the reader thinks that the story of the feud between the villains and Scrooge McDuck are cool, without thinking about the reality of violence in the real world and what is behind it all. For authors, the comic was a popular literary childrens because the Visual interesting, triple effect obtained, as well as visual literature that is full of meaning that is favored by adults. For, in the body of an adult was there the soul children develop.

\section{REFERENCES}

Ajidarma, Seno Gumira. (2011). Panji Tengkorak: Kebudayaan Dalam Perbincangan. Disertasi di Program Kedoktoran, Universitas Indonesia. Jakarta: Kepustakaan Populer Gramedia.

Ashley, Bob. (1989). The Study of Popular Fiction: A Source Book. Philadelphia: The University of Pennsylvania Press.

(1989). Reading Popular Narrative; Formula, genre and the structuralist analysis of narrative, Vladimir Propp, Morphology of the folk tale. London, New York: Leicester University Press.

Cawelti, John G. (1976). "Adventure, Mystery amd Romance: Formula Story as Art and popular Culture”. Chicago: The University of Chicago Press.

McCloud, Scott. (2001). Understanding Comics (Memahami Komik).Jakarta: Kepustakaan Populer Gramedia. 
(2008).Reinventing Comics (Mencipta Ulang Komik).Jakarta: Kepustakaan Populer Gramedia.

Rosa, Don. (2012). Kisah Hidup Paman Gober (Edisi Bundel). Jakarta: Kompas Gramedia. http://libgen.io/comics/index.php?thelifeandtimesofscroogemcduck\# downloaded at January 2018 